tion of rock phosphate with soda ash; a further forty tons of the silicophosphate obtained have been prepared in the pilot rotary kiln for field experiments. The ceramics branch has developed a new technique for building bricks by bonding non-plastic quarry waste with the minimum of highly plastic clay and firing in a kiln to give a building block cheaper than dressed natural stone. Advice has been given to the commercial pottery branch of the Industrial Management Board, and the production of alternative lowcost building materials has received attention, particularly murram, a natural formation consisting of coarse materials, rotten rock or concretionary iron ironstone bonded with clay. Promising results have been obtained in the extraction of pyrethrins from fresh flowers by a three-stage counter-current process, and a hæmoglobin digestion method has been developed for the assay of papain. Further work has been carried out in connexion with the manufacture of totaquina, including improved methods of analysis and study of the conditions for the maximum recovery of quinine and cinchonidine. A method of testing samples of diatomites as filter aids was standardized, and the amelioration of the pollution of streams by effluents from coffee and sisal factories was studied intensively; small-scale plant trials indicate that at least 90 per cent purification of the coffee effluents can be effected by biological filtration. Work was completed on the tannin content of different varieties of mangrove bark.

\section{World Supplies of Oils and Fats}

ThE address "Rebuilding Europe's Fat Supplies the Problem and How to Meet It", delivered by the chairman of Lever Brothers and Unilever, Ltd., at the annual general meeting of that company on September 8, has been reprinted, with a graph and a series of statistical appendixes (Pp. 24. Lever Bros. and Unilever, Ltd., London). The survey of pre-war, war-time and post-war supplies leads Mr. G. Heyworth to the conclusion that there is at present an annual world shortage of some four million tons of oils and fats, and although supplies can be increased, the process will be slow. The tendency for producing countries to consume a greater part of their own products, as well as the tendency towards a heavier consumption of milk, particularly in the United States and Great Britain, and the serious decline in the production of oils and fats in Western Europe, are new contributing factors; and it is estimated that the world production for 1947 will have been about two and a half million tons below the pre-war figure. Allowing for the increase in world population, the gap between supply and demand is too big to permit abandonment of Government controls in either Great Britain or Holland at present; but the control system in Western Europe can be operated so as to improve the terms of trade by more effective combination in the purchase of raw materials and by the removal of subsidies on the finished products.

Mr. Heyworth is emphatically of the opinion that the earliest abolition of the subsidies on food in Britain is essential. Home production in the countries of Western Europe can be increased and production in overseas territories, which were exporters before the War, must be restored to the full, and high priority given to the re-establishment of conditions which make this possible. Additional production must be found by bringing into cultivation unused tracts of land, as typified by the East African Ground- nut Scheme, and additional amounts of detergents should be manufactured from materials derived from mineral oil. He even suggested the temporary suspension of the present international limitation on the catching of whales. Finally, he urged better utilization of existing production facilities generally, and the forgoing of expenditure on activities which do not immediately contribute to the alleviation of essential shortages.

\section{Control of Atomic Energy}

Tне Society of Calvinist Lawyers and the Christian Society of Scientists and Physicians in the Netherlands held a meeting at Amersfoort, Netherlands, during November 15-17, 1947, to discuss the problem of atomic energy. Addresses were delivered by $\mathrm{Dr}$. D. J. Lock on "The Military Aspect", Dr. C. C. Jonker on "The Economic Aspect", Dr. Gezina H. J. van der Molen on "The International Aspect", and Dr. R. Schippers on "The Ethical Aspect". The meeting was presided over by the presidents of the two societies, Prof. P. S. Gerbrandy and Prof. G. J. Sizoo. A number of resolutions were adopted, some dealing with spiritual aspects of the problem, and others with the material side. Among the latter, it was noted that the atomic weapon itself does not bring about an essential change in warfare, although the extent of its destructive power is so great that it is not possible to restrict the force of arms to purely military objects. On account of this exceptional character, international control and inspection of the atomic weapon is imperative. Prohibition of the atomic weapon without international control must be rejected as absolutely inefficient in view of former experience with similar prohibitions. Since the application of atomic energy for peaceful purposes leads inevitably to the possibility of preparing for military applications, the production and use of atomic energy for peaceful purposes come within the sphere of international law, and should be put under the supervision and inspection of an international organisation. It was resolved that national sovereignty is not a legal ground for rejecting international control of atomic energy. All nations, it was concluded, should, in view of the far-reaching effects of atomic energy problems, make the utmost effort to find peaceful solutions of international differences.

\section{Horace Wells and Anæsthesia}

A CENTURY ago, on January 24, 1848, one of the principal actors in the drama of anæsthesia died in prison by his own hand at the age of thirty-three. Born at Hartford, Vermont, on January 21, 1815, Horace Wells studied dentistry at Boston, and practised at Hartford, Connecticut. The idea of inhalation anæsthesia occurred to him on December 10,1844 , during an exhibition of 'laughing gas' by a New York showman, Gardner Quincy Colton, when a young man, Sam Cooley by name, under the influence of the gas severely bruised his leg without apparently feeling any pain. The following day Wells had a troublesome wisdom tooth painlessly removed under nitrous oxide. In January 1845 he went to Boston to demonstrate his discovery at the Harvard Medical School. The experiment went wrong, and the young dentist left the theatre with the words 'charlatan' and 'humbug' ringing in his ears. His physical and mental health now began to decline. The last chapter of his life is steeped in obscurity. On January 24, 1848, in Tombs Prison, New York, he committed suicide under chloroform anæsthesia-slashing his 